\title{
Is Altering Grazing Selectivity of Invasive Forage Species With Patch Burning More Effective Than Herbicide Treatments?
}

\author{
D. Chad Cummings, ${ }^{1}$ Samuel D. Fublendorf, ${ }^{2}$ and David M. Engle ${ }^{3}$
}

\author{
Authors are ${ }^{1}$ Research Technician and PhD Candidate, Department of Natural Resource Ecology and Management, Oklahoma State University, \\ Stillwater, OK 74078; ${ }^{2}$ Professor, Department of Natural Resource Ecology and Management, Oklahoma State University, Stillwater, OK 74078; and \\ ${ }^{3}$ Department Head, Natural Resource Ecology and Management, Iowa State University, Ames, IA 50011.
}

\begin{abstract}
Invasion of rangeland by exotic forage species threatens ecosystem structure and function and can cause catastrophic economic losses. Herbicide treatments often are the focus of management efforts to control invasions. Management with the fire-grazing interaction (or patch burning) might suppress an invasive forage species that has grazing persistence mechanisms developed apart from the fire-grazing interaction. We studied tallgrass prairies invaded by sericea lespedeza (Lespedeza cuneata [Dum.Cours.] G. Don) to compare rate of invasion between traditional management and management with patch burning, to evaluate the effect of burn season on sericea lespedeza invasion within pastures managed with patch burning, and to correlate canopy cover of sericea lespedeza to canopy cover of other functional groups with and without herbicides. Sericea lespedeza canopy cover increased from 1999 to 2005 in both traditional- and patch-burn pastures, but sericea lespedeza increased from 5\% to $16 \%$ canopy cover in traditionally managed pastures compared to $3 \%$ to $5 \%$ in the patch-burn pastures. Rate of increase in canopy cover of sericea lespedeza was less in patches burned in summer $\left(0.41 \% \cdot\right.$ year $\left.^{-1}\right)$ than in patches burned in spring $\left(0.58 \% \cdot\right.$ year $\left.^{-1}\right)$ within patch-burn pastures. Most plant functional groups, including forbs, were weak-negatively correlated with canopy cover of sericea lespedeza. Although herbicide application reduced mass of sericea lespedeza, other components of the vegetation changed little. Herbicide treatments temporarily reduced sericea lespedeza but did not predictably increase other plant functional groups. Patch burning reduced the rate of invasion by sericea lespedeza by maintaining young, palatable sericea plants in the burn patch, and could play a vital role in an integrated weed management strategy on rangelands.
\end{abstract}

\section{Resumen}

La invasión de los pastizales por especies forrajeras exóticas amenaza la estructura y función de los ecosistemas, y pueden causar pérdidas económicas catastróficas. Los tratamientos con herbicidas a menudo son el enfoque de las acciones de manejo para controlar las invasiones. El manejo con la interacción apacentamiento/fuego (o quema de parches) pudiera suprimir una especies forrajera invasora con mecanismos de resistencia al apacentamiento desarrollados aparte de la interacción apacentamiento/ fuego. Estudiamos praderas de zacates altos invadidas por "Sericea lespedeza" (Lespedeza cuneata [Dum.-Cours.] G. Don) para comparar la tasa de invasión entre el manejo tradicional y el manejo con quema de parches, para evaluar el efecto de la época de quema en al invasión de "Sericea lespedeza" dentro de praderas manejadas con quema de parches, y correlacionar la cobertura de copa de "Sericea lespedeza" con la cobertura de copa de otros grupos funcionales con y sin herbicidas. De 1999 al 2005, la cobertura de copa de "Sericea lespedeza" se incrementó tanto en los potreros con manejo tradicional como en los de quema de parches, pero la "Sericea lespedeza" aumentó su cobertura de copa de $5 \%$ a $16 \%$ en los potreros manejados tradicionalmente y de $3 \%$ a $5 \%$ en los que recibieron quema de parches. Dentro de las praderas con quema de parches, la tasa de incremento de la cobertura de copa de "Sericea lespedeza" fue menor en los parches quemados en verano $\left(0.41 \% \cdot\right.$ año $\left.^{-1}\right)$ que en los quemados en primavera $\left(0.58 \% \cdot\right.$ año $\left.^{-1}\right)$. La mayoría de los grupos funcionales, incluyendo las hierbas, estuvieron débilmente correlacionados negativamente con la cobertura de copa de la "Sericea lespedeza." Aunque la aplicación de herbicida redujo la biomasa de "Sericea lespedeza," los otros componentes de la vegetación cambiaron poco. Los tratamientos de herbicida redujeron temporalmente la "Sericea lespedeza," pero no incrementarían, en forma predecible, los otros grupos funcionales de plantas. La quema de parches redujo la tasa de invasión de "Sericea lespedeza" al mantener dentro de los parches quemados plantas de jóvenes y apetecibles de "Sericea lespedeza," y pudiera jugar un papel vital en una estrategia de manejo integrado de maleza en los pastizales.

Key Words: Chinese bush clover, disturbance ecology, fire ecology, grazing management, heterogeneity, herbivory, invasion, macro-ecology, sericea lespedeza

This research is funded by the Oklahoma Agricultural Experiment Station, USDA-NRI Managed Ecosystems Program (02-00777), USDA-NRI Biology of Weedy and Invasive Species and the Joint Fire Sciences Program. This article is published with the approval of the director, Oklahoma Agricultural Experiment Station.

Correspondence: D. Chad Cummings, Oklahoma State University, 008 Ag Hall, Stillwater, OK 74078. Email: dchad.cummings@okstate.edu

Manuscript received 30 May 2006; manuscript accepted 28 February 2007.

\section{INTRODUCTION}

Invasive plant species alter native plant communities, and their rate of invasion depends upon the structure of native communities they invade (Woods 1993; Morgan 1998; Symstad 2000; Brandon et al. 2004). In addition, the total 
area of rangelands in the United States decreased by 4.4 million ha from 1982 to 1997, while pasturelands decreased by 49 million ha during the same time period due to urbanization, erosion, and cultivation (National Resources Inventory 1997). Recently, invasive species in rangelands and other agricultural lands have cost US agricultural production an estimated $\$ 33$ billion each year and further threaten rangeland resources (Mack et al. 2000; Pimental et al. 2002). Given the loss of grasslands, and the economic costs of invasive species, it is especially important to study invasive species biology and ecology, and provide options to manage them.

Many exotic species have been deliberately introduced into the United States as forage species only to become aggressive invaders once they escape cultivation. Some examples include kudzu (Pueraria montana [Luor.] Merr.), Old world bluestem (Bothriochloa ischaemum [L.] Keng), and tall fescue (Festuca arundinacea Schreb.). These species are unique from nondeliberately introduced, exotic invaders because they are selected for traits that promote establishment and persistence in grazed monocultures. These traits include aggressive growth rates, prolific seed production, multiple modes of reproduction (propagule and vegetative), and traits that encourage persistence in grazed ecosystems (e.g., chemical compounds, high stem-to-leaf ratio) (Barnes et al. 2003). As a result, exotic forage species are unique because they are selected for traits that assure their establishment and persistence in grazed monocultures, traits which also facilitate their invasion into diverse native ecosystems (Clubine 1995; Brandon et al. 2004).

Sericea lespedeza (Lespedeza cuneata [Dum.-Cours.] G. Don) is an herbaceous, long-lived perennial legume introduced into the United States in 1896 from eastern Asia. Sericea lespedeza has been used extensively for forage production, erosion control, and land reclamation since the 1930s. The USDA introduced sericea lespedeza as a forage species, in part because it is persistent once established. This persistence in grazed ecosystems is due to nonpreference by grazing animals later in the growing season. Although highly nutritious and palatable early in its phenology, maturity leads to avoidance by grazers resulting from decreased digestibility (Clarke et al. 1939; Stitt and Clarke 1941; Donnelly 1954). Phenolic polymers (called condensed tannins), located throughout the plant (Mosjidis et al. 1990), also decrease digestibility and have been shown to cause gastrointestinal malaise (or stomach discontent) in some ruminants (Provenza et al. 1990).

Control of sericea lespedeza has typically focused on using selective herbicides. These herbicides, such as metsulfuronmethyl (methyl 2-[[[[(4-methoxy-6-methyl-1,3,5-triazin-2-yl)amino $]$ carbonyl $]$ amino $]$ sulfonyl $]$ benzoate $),$ triclopyr ([(3,5, 6-trichloro-2-pyridinyl)oxy]acetic acid), and tank mixes of triclopyr and other herbicides, have been effective in seasonlong control of sericea lespedeza (Altom and Stritzke 1992; Koger et al. 2002). However, chemical control does not provide permanent eradication of sericea lespedeza. Due to the prolific seed production (Stitt and Clarke 1941; Donnelly 1954) the soil seed bank provides new sericea lespedeza invaders for multiple years following herbicide treatment. Repeat application of selective herbicides for invasive species control is economically taxing and has profound negative impacts on native forbs and legumes in rangelands (Koger et al. 2002).

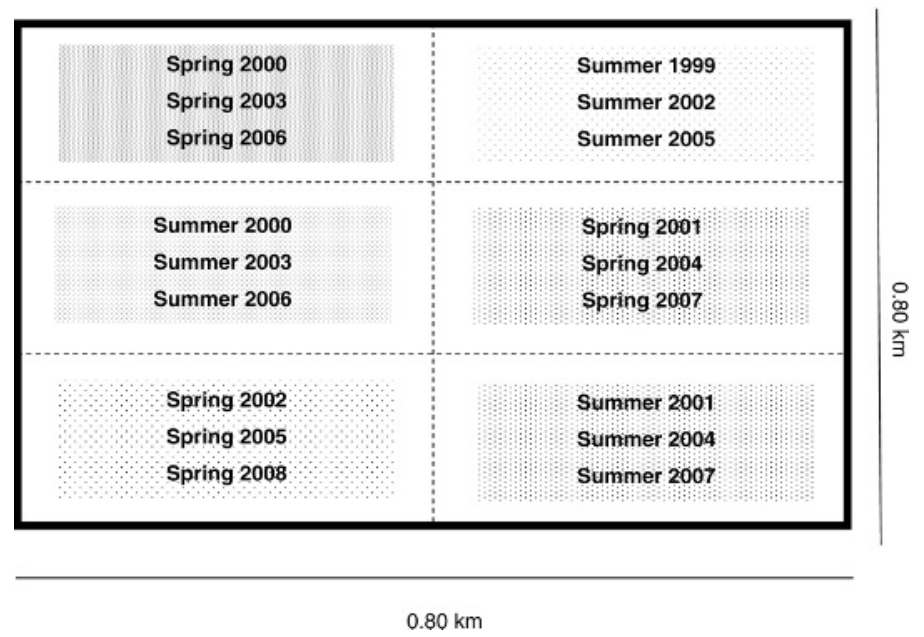

Figure 1. Prescribed burn treatment schedule for patches within the patch-burned pasture units. Within each pasture small patches are burned in multiple seasons, followed by focused grazing disturbance of the burned patch.

An alternative approach to managing invasive forages with persistence mechanisms, which maintain their dominance under grazing (i.e., secondary chemicals, growth form), is to alter the relationship between palatability and seasonality with intensive selectivity by grazing animals, and management that reduces the expression of persistence mechanisms (e.g., fire). An example of this alteration in grazing preference is patchburning (Fuhlendorf and Engle 2001, 2004), which reduces selection on individual plants and increases selection of all species within a burned patch. Under patch-burned systems, portions of an individual pasture unit are burned in the spring and summer of each year (Fig. 1) in an attempt to create a firegrazing interaction. Cattle preferentially graze the recently burned patch following a prescribed burn and avoid other patches with longer times since fire (patch-burn treatment, in this study). The result is a shifting mosaic that includes unburned areas that are not likely to be grazed but have accumulated fuel, recently burned patches that attract livestock and are not likely to get burned, and several patches in transitional stages of succession. Grazing selectivity patterns are changed from that of the individual species or feeding station to an entire burned patch, resulting in lower grazing preference of individual species across the burned area.

Therefore, we compared sericea lespedeza invasion under rangeland management based on patch-burning to invasion under traditional rangeland management. In addition to studying the fire-grazing interaction, we also wanted to evaluate the effects of traditional approaches to managing invasive species with herbicides. We compared the effect of standard rangeland herbicides on sericea biomass and the response of other plant functional groups to sericea control. Our specific objectives were to: 1) confirm that sericea lespedeza invades rangelands and identify differences in invasion rate between traditional management and patch burning, 2) determine what effect season of burn has on sericea lespedeza invasion, and 3) compare the response of native plant functional groups to sericea invasion with the fire-grazing 
interaction and with herbicide applications. Our hypotheses were that sericea lespedeza would invade at a reduced rate in the patch-burn treatment compared to the traditional management treatment, and summer fires would be more effective at suppressing the sericea invasion than spring fires. In addition, all plant functional groups would be negatively affected by sericea lespedeza invasion, but these effects would be more pronounced with increased invasion.

\section{METHODS}

\section{Study Regions}

To address our objectives, we established multiple study locations in the southern Great Plains. One study location was used to address the first two objectives concerning the invasion dynamics and impact of sericea lespedeza on rangeland vegetation. This study area (Experiment 1; see also Fuhlendorf and Engle 2004; Anderson et al. 2006; Fuhlendorf et al. 2006) utilized fire and grazing as management options to alter grazing patterns and selectivity of forage within experimental units. Nine additional study locations were used to address the third objective, which investigated the relationship between sericea lespedeza biomass and native community biomass following herbicide application. These herbicide studies (Experiment 2) were located throughout central and southern Oklahoma over several years. Throughout the manuscript, the two types of studies will be explained separately for clarity.

For the patch-burn study (Experiment 1), the experimental area was located in north central Oklahoma on the Oklahoma State University Range Research Station (lat 36 $16^{\prime} \mathrm{N}$; long $97^{\circ} 09^{\prime} \mathrm{W}$ ) located $21 \mathrm{~km}$ southwest of Stillwater, Oklahoma. The region is dominated by a continental climate with an average of 204 frost-free days and $846 \mathrm{~mm}$ annual precipitation, $65 \%$ of which falls from May to October. The vegetation matrix is tallgrass prairie with intermittent patches of cross timbers habitat on shallow uplands. Dominants of the tallgrass prairie in the area include little bluestem, Schizacharium scoparium (Michx.) Nash; big bluestem, Andropogon gerardii Vitman; Indiangrass, Sorghastrum nutans (L.) Nash; switchgrass, Panicum virgatum L.; and tall dropseed, Sporobolus asper (Michx.) Kunth. Minor grasses include Bouteloua curtipendula (Michx.) Torr., and Dicanthelium oligosanthes (Schult.) Gould. The dominant forbs in the area are western ragweed, Ambrosia psilostachya DC. and common broomweed, Gutierrezia dracunculoides (DC.) S. F. Blake. The cross timbers communities are dominated by post oak, Quercus stellata Wang.; blackjack oak, Q. marilandica Münchh.; and hackberry, Celtis spp. The area is also invaded by eastern redcedar, Juniperus virginiana L. and sericea lespedeza. Initial sericea lespedeza invasion was light in the area, making up $0 \%-$ $7 \%$ of the plant composition. Prescribed fire was applied periodically to all study areas for eastern red cedar control prior to the experiment initiation.

The herbicide trials (Experiment 2) were located on private ranches across central Oklahoma (Koger et al. 2002). The general vegetation composition was similar to that of the patchburn study explained above. The herbicide trials were located in southern and north central Oklahoma on tallgrass prairie that previously were managed with variable grazing and fire regimes and periodic broad spectrum herbicide applications. Initial sericea lespedeza invasion was heavy in all study areas, making up $35 \%$ of the plant composition on average. Nine herbicide trials in all were used in the initial data analysis. We used biomass means from the herbicide trials to evaluate the objectives of controlling sericea and increasing other grass and forb biomass. Unlike Koger et al. (2002) we analyzed a combined data set from nine herbicide trials, which compared similar herbicide treatments, to determine trends in the plant components following herbicide application.

\section{Experimental Design}

Experiment 1-Patch Burning vs. Traditional Grazing Management. In 1999, a completely randomized design (CRD) experiment was established to test the effects of patch-burning on vegetation dynamics (Fuhlendorf and Engle 2004). Six individual pastures $(0.8 \times 0.8 \mathrm{~km})$ were assigned one of two treatments. The treatments were: 1 ) a patch burned treatment (the application of the fire-grazing interaction) and 2) traditional management for rangelands in the area (experimental design analogous to Anderson et al. 2006; Fuhlendorf et al. 2006). The patch-burned treatment pastures $(n=3,0.8 \times$ $0.8 \mathrm{~km})$ consisted of 6 distinct patches within a pasture. Annually, one-sixth of the pasture was burned in the spring and one-sixth burned in the late summer, which created a mosaic of plant diversity and structure across the pasture unit (Fig. 1). As a result, patches of heavy disturbance were included within a landscape of patches that vary with time since focal disturbance (Fuhlendorf and Engle 2001, 2004). Traditional management pastures $(n=3,0.8 \times 0.8 \mathrm{~km})$ were prescribed burned every 3 years in the spring for Juniperus virginiana control. Thus, the only difference between treatments was the timing and pattern of the burns, with similar amounts of fire across the management units. From 1999 to 2005, both treatments were moderately grazed by mixed-breed cattle with a stocking rate of $0.83 \mathrm{ha} \cdot \mathrm{AUM}^{-1}$ (AUM $=$ animal unit month) (Gillen et al. 1991). Annual vegetation cover of plant functional groups was measured by ocular estimation each summer beginning in 1999. Random subsampling with 30, $0.1 \mathrm{~m}^{2}$ quadrats per patch monitored functional groups including tallgrasses, little bluestem, other perennial grasses, annual grasses, forbs, sericea lespedeza, other legumes, litter, and bare ground. Sericea lespedeza invasion was defined as the increase in percent vegetative cover over time.

Experiment 2-Herbicide Studies. The herbicide trials (1997 through 2001) were designed as randomized complete blocks with 3 or 4 replications $(n=3$ or 4$)$ and $15-18$ different herbicide treatments and associated controls, depending on the study site. Herbicide treatments were made at various stages in sericea lespedeza development including the single stem, branched stem, and flowering stages (Koger et al. 2002). From 1997 to 2001 in some cases, vegetative components were visually estimated for forage composition prior to hand clipping 2, $0.4 \mathrm{~m}^{2}$ plots per experimental unit. Grass, forb, and sericea lespedeza biomass were determined as a percentage of the total biomass. A net change in component biomass was calculated for herbicide studies that had more than 1 year of 
forage data, by subtracting the first season biomass from the last season biomass. This approach addressed the broad hypothesis that herbicide applications were effective at managing sericea lespedeza to increase grass and other forb biomass. To identify relationships between changes in sericea lespedeza biomass and changes in native plant biomass, we used a macro-ecological approach. Each data point $(n=251)$ represents the sericea lespedeza biomass (x-axis) and grass or forb biomass (y-axis) from 1 treatment in 1 of the 9 herbicide trials. Because herbicide effectiveness is also a key issue, we analyzed the data in 2 separate methods. First, the entire data set was analyzed to identify any relationships between sericea lespedeza biomass and native plant biomass across treatments (including effective, non-effective, and no herbicide treatments). The second analysis included only the treatments that resulted in adequate control of sericea lespedeza (90\% control or greater; sensu Koger et al. 2002) in our analysis.

\section{Data Analyses}

Experiment 1-Patch-burn study. The rate of sericea lespedeza invasion in the patch-burn study (Experiment 1) was calculated 2 ways. First, means for invasion were generated from all 0.1$\mathrm{m}^{2}$ plots of each treatment per year $\left(n=3 \cdot\right.$ year $\left.^{-1}\right)$. Annual vegetative cover was regressed over year. Increased invasion was defined as an increase in sericea lespedeza cover for this study. Though we reported results from regression analysis, it should be noted that regression was only used to find rates of invasion (i.e., the slope of the trend line) and not strength of the relationship between year and annual sericea cover. The data were also analyzed with repeated measures analysis of variance (ANOVA) for means ( $\alpha=0.05$ significant, $\alpha=0.10$ weakly significant) using PROC MIXED procedure in SAS (SAS 2000). Year was not treated as the related variable because new seedlings could have germinated each year. In addition, individual $t$-tests were run to compare each treatment at each year in sericea lespedeza cover.

Using only the patch-burn treatment pastures, the effects of burn season on invasion were tested. Each patch in the patchburn treatment was designated as a spring or summer burn, depending on respective season of prescribed fire (Fig. 1). The mean sericea lespedeza cover consisted of all patches within a given burn season for each year following a prescribed burn $\left(n=3 \cdot\right.$ season $^{-1} \cdot$ year $\left.^{-1}\right)$. Least squared means were compared across years since fire for each burn season (PROC MIXED in SAS, $\alpha=0.05$ ).

To test the effect of increasing sericea lespedeza cover on the native functional groups, Pearson's correlation coefficients (PROC CORR procedure in SAS) were used to identify significant $(\alpha=0.05$ and 0.10$)$ relationships with sericea lespedeza and other functional groups at the plot, patch, and pasture scales. It should be noted that these data are only for use as descriptive statistics to observe the effect of increasing sericea lespedeza on the native plant functional groups at multiple spatial scales. Individual experimental units were broken down into their component parts (subsamples, time since fire, and season of fire) to observe the effects of invasion at each level because ecological phenomena often have an associated inherent scale at which they occur (Turner et al. 1989).
Experiment 2-Herbicide Studies. In the herbicide trials the data means of sericea lespedeza biomass, grass biomass, and forb biomass were compared using Pearson's correlation coefficients (PROC CORR procedure in SAS) to identify significant $(\alpha=0.05)$ relationships with sericea lespedeza. The first analysis included all herbicide treatments. The second analysis only included single applications of triclopyr, metsulfuron-methyl, or fluroxypyr (2-(4-amino-3,5-dichloro-6fluoro-pyridin-2-yl)oxyacetic acid) herbicides at the rates depicted in Koger et al. (2002) to determine if herbicide effectiveness played some role in the relationship between sericea lespedeza cover and cover of native plants. Production from within treatment year, one year following treatment, and two years following treatment (where available) were used in the correlation analysis.

\section{RESULTS}

\section{Experiment 1-Patch Burning vs. Traditional Grazing Management}

Sericea lespedeza cover increased at a much greater rate in traditionally managed units than in the patch-burn treatment (Fig. 2). Repeated measures ANOVA indicated significant year $(P<0.001)$ and weakly significant treatment by year interaction $(P=0.087)$. When looking at each treatment and year individually, at the initiation of the experiment in 1999 , the two treatments did not differ significantly $(P=0.11)$ in sericea lespedeza cover. By 2000, the traditionally managed treatment had increased significantly more than the patch-burn treatment $(P=0.02)$, which showed signs of fluctuation rather than true invasion with positive and negative annual changes. The divergence between treatments continued throughout the study period. Average sericea lespedeza cover increased in the traditionally managed pastures at a rate of $1.95 \%\left(r^{2}=0.997\right)$ per year, whereas patch-burned pastures only increased at $0.47 \%\left(r^{2}=0.676\right)$ each year (Fig. 2$)$. This is almost a fourfold greater rate of increase in the traditionally managed pastures than to the patch-burned pastures.

Within the patch-burn treatment, season of prescribed burn also had an effect on the invasion rate. Mean sericea lespedeza cover was statistically similar in summer and spring burn patches in the first and second year following burn, but became significantly higher $(P=0.046)$ for spring burns in the third year suggesting that summer fires have decreased the rate of sericea lespedeza invasion more than spring fire. In addition, analysis of overall invasion rates indicated sericea lespedeza cover in the spring patch burns increased at almost twice the rate of summer patch burns from 1999 to $2005(0.65 \%$ and $0.36 \%$ cover increase per year, for spring burns and summer burns, respectively). Annual invasion fluctuated from positive to negative rates of increase in cover for both burn seasons (data not shown). These fluctuations could result from areas of intensive sericea lespedeza utilization in the season following fire within the patch-burn units. Although neither season had a net negative rate of increase, large fluctuations in invasion rate indicate that this species might cycle with variable fire and weather patterns in the patch-burn treatment. 


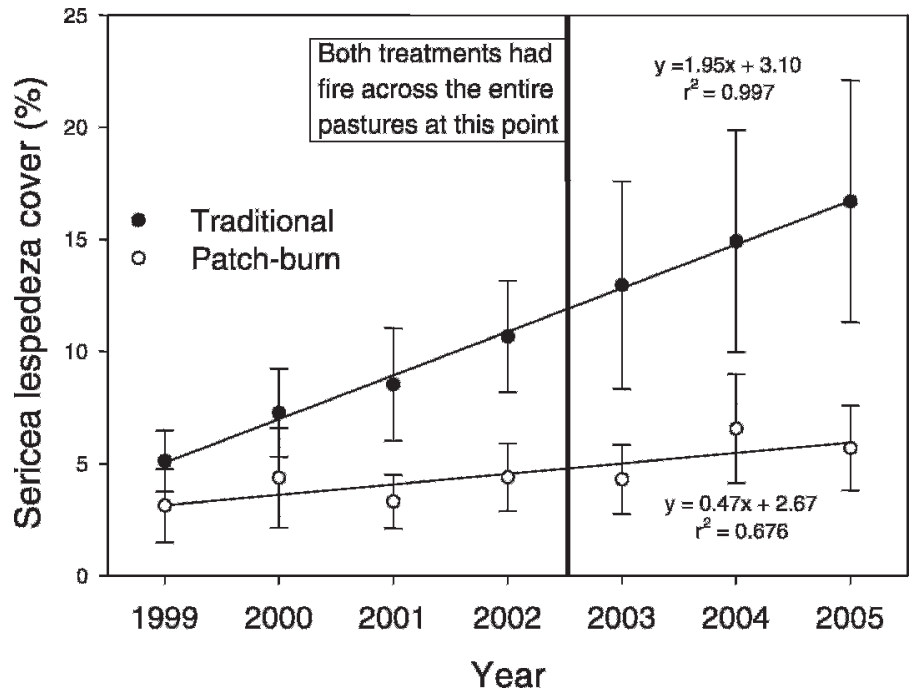

Figure 2. Sericea lespedeza invasion over time in the traditional management and patch-burn treatments. Error bars indicate one standard error.

\section{Experiment 1-Response of Native Plant Functional Groups to Sericea lespedeza Invasion With the Fire-Grazing Interaction}

The third objective was to determine the relationship between sericea lespedeza and the other functional groups in the patchburn and traditionally managed treatments. Although not a specific part of our objectives, these relationships were analyzed at multiple scales of observation, because ecological phenomena often differ due to the scale of observation (Turner et al. 1989). Sericea lespedeza increases in cover resulted in decreased cover for most functional groups in our study, although some positive relationships also existed (Table 1). Recall that the experimental units $\left(n=3 \cdot\right.$ treatment $^{-1}$. year ${ }^{-1}$ ) were broken down into their component parts for these descriptive analyses. At the plot scale $\left(0.1 \mathrm{~m}^{2} ; n=3240\right.$ per treatment), weak negative correlations were found with tallgrass, little bluestem, other perennial grasses, and forbs for both treatments. In the patch-burn treatment, litter showed a slight positive correlation, whereas bare ground was negatively correlated. At the patch scale $\left(0.1 \mathrm{~km}^{2} ; n=108\right)$, functional groups in the traditional treatment showed more correlations with sericea lespedeza than the patch-burn treatment (Table 1). Tallgrass, little bluestem, and forbs showed negative correlations with sericea lespedeza in the traditionally managed treatment, whereas legumes, litter, and bare ground had positive correlations. The patch-burn treatment had only two significant $(P<0.05)$ correlations at the patch scale. At the pasture scale $\left(0.64 \mathrm{~km}^{2} ; n=18\right)$, there was only one significant correlation for either treatment. In the traditional treatment, forbs showed a strong negative correlation $(P=0.015)$ with sericea lespedeza, which increased in magnitude of the relationship (i.e., numerically greater correlation coefficients) as scale increased (Table 1). Although these data indicate significant relationships $(P<0.05)$ between sericea lespedeza cover and cover of the other functional groups, it should be noted that the relationships are extremely weak given the large sample size at the plot level $(n=3240)$. Other factors, biotic and abiotic, appear to have a greater impact on the cover of forbs and grasses than sericea lespedeza.

\section{Experiment 2-Response of Native Plant Functional Groups to Sericea Lespedeza Invasion With Herbicide Applications}

When considering all data points in this broad scale study (Experiment 2), including both effective and ineffective sericea lespedeza control with herbicide applications, we found no clear relationship between sericea lespedeza biomass to either forb or grass production (Fig. 3). The strongest relationship $\left(r^{2}\right.$ $=0.04 ; n=251$ ) occurred between sericea lespedeza biomass and forb biomass but accounted for only $4 \%$ of the total variation. When we included only data from herbicide treatments, we found no relationship between grass or forb components and sericea lespedeza. This held true for herbicide treatments up to 3 years following herbicide application. In our studies across multiple sites on the southern Great Plains, we could not identify any meaningful relationships (linear or nonlinear) between sericea lespedeza biomass and either grass or forbs.

For herbicide treatments in which we had more than one year of biomass data, the change in time in biomass of sericea lespedeza was also regressed by grasses and forbs to determine if successful sericea lespedeza control results in predictable

Table 1. Pearson's correlation coefficients $(r)$ for significant (PROC CORR, $P<0.05$ ) linear relationships of functional group canopy cover with sericea lespedeza canopy cover at the plot $\left(0.1 \mathrm{~m}^{2}\right)$, patch $\left(0.1 \mathrm{~km}^{2}\right)$, and pasture $\left(0.64 \mathrm{~km}^{2}\right)$ scales of observation over 7 years.

\begin{tabular}{|c|c|c|c|c|c|c|c|c|}
\hline \multirow[b]{2}{*}{ Treatment $^{2}$} & \multicolumn{8}{|c|}{ Functional group ${ }^{1}$} \\
\hline & TG & LB & OTHPER & ANNGR & FORB & LEGUME & LITTER & $\mathrm{BG}$ \\
\hline \multicolumn{9}{|l|}{ Plot $(n=3240)$} \\
\hline Traditional & -0.161 & -0.222 & -0.110 & & -0.123 & & & \\
\hline Patch-burned & -0.064 & -0.136 & -0.124 & & -0.043 & & 0.109 & -0.096 \\
\hline \multicolumn{9}{|l|}{ Patch $(n=108)$} \\
\hline Traditional & -0.331 & -0.259 & & & -0.313 & 0.344 & 0.192 & 0.314 \\
\hline Patch-burned & & & & & & 0.204 & 0.204 & \\
\hline \multicolumn{9}{|l|}{ Pasture $(n=18)$} \\
\hline Traditional & & & & & -0.563 & & & \\
\hline Patch-burned & & & & & & & & \\
\hline
\end{tabular}



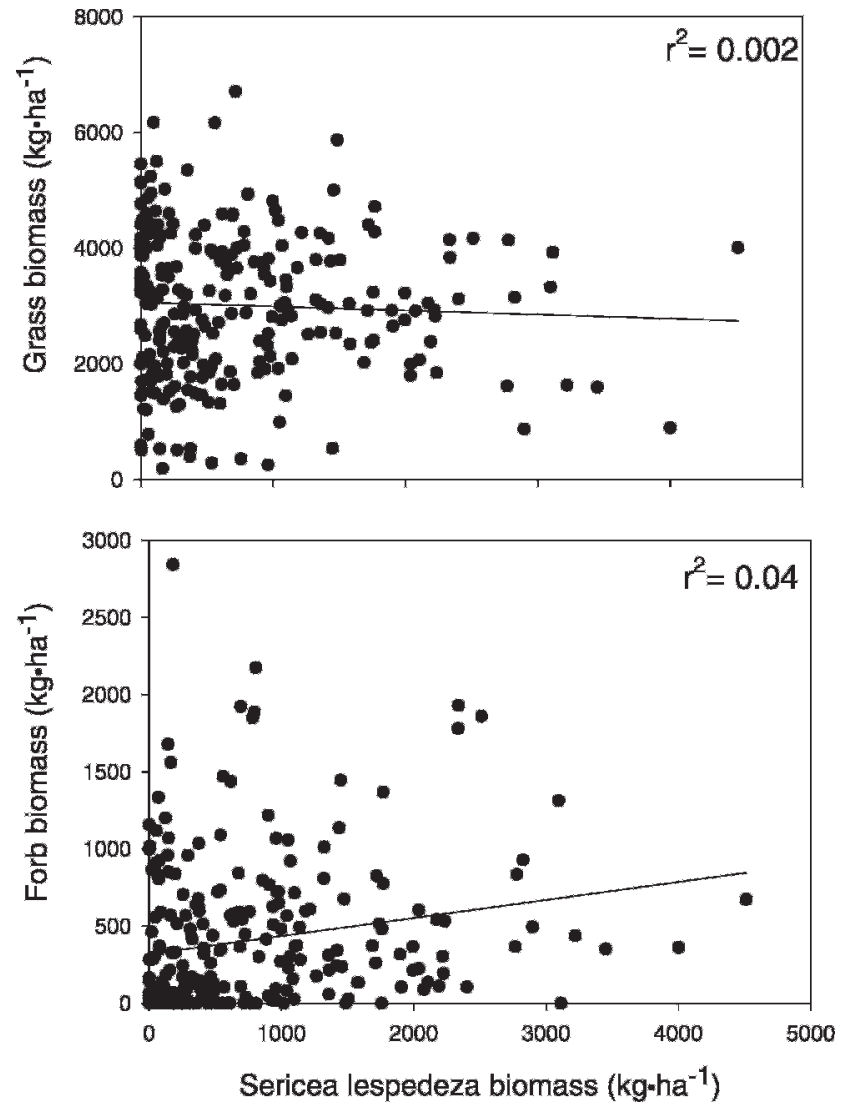

Figure 3. Regression analysis of sericea lespedeza biomass production and grass biomass production (top) or forb biomass production (bottom) in nine herbicide trials throughout central and eastern Oklahoma from 1997 to 2001.

increases of other functional groups (Fig. 4). Using only the most effective sericea lespedeza herbicide treatments (Koger et al. 2002), there was a weak negative response in grass biomass (Fig. 4 top) to increasing amounts of sericea lespedeza biomass $\left(n=23\right.$; a regression slope of $\left.-2.99 ; r^{2}=0.50\right)$. There was no relationship between change in sericea lespedeza biomass and change in forb biomass over time (Fig. 4 bottom). In all, there was only one instance of biomass replacement by sericea lespedeza over time and it occurred within the grass component. In all other instances there was no predictable replacement of sericea lespedeza forage by grass or forb forage. This broad analysis of herbicide studies had similar conclusions to previous studies on nonfertilized and eroded sites (Koger et al. 2002), which reported minimal replacement of biomass when herbicides eliminated the existing sericea lespedeza invasion.

\section{DISCUSSION}

Given the prediction of vast economic costs and modification of native ecosystems by invasive species (Pimental et al. 2002), it is especially important to study invasive species biology and ecology to understand the effects of invasion. We need a comprehensive understanding of invasion mechanisms and effects to provide land management options that efficiently deter invasion. Typically, the literature suggests that invasive
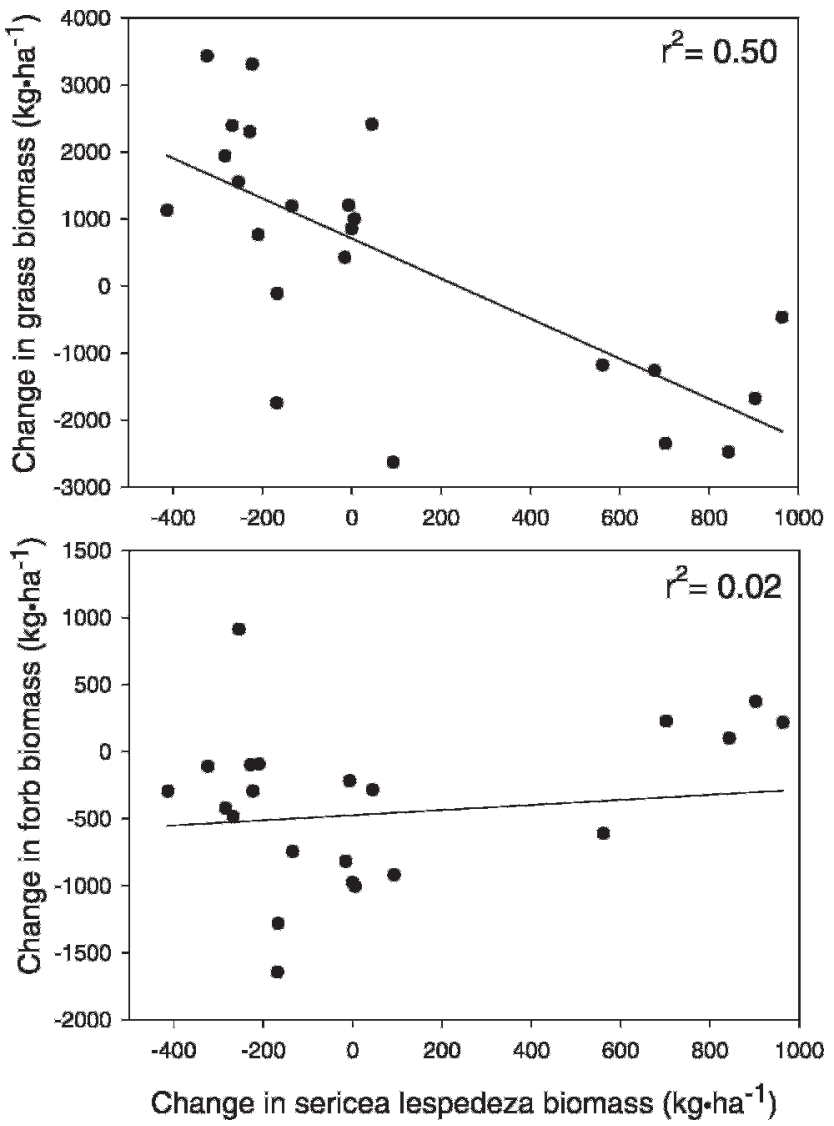

Figure 4. Data from the most effective herbicide treatments with multiple years of biomass production data in central and eastern Oklahoma from 1997 to 2001. Points indicate the change in sericea lespedeza biomass production in relation to the change in grass (top) and forb (bottom) biomass production from the first year of data collection to the last year of data collection for only the best herbicide treatments in five herbicide trials (Koger et al. 2002).

plant species affect, and are affected by the plant communities they invade, correlating to major shifts in the existing plant community (Woods 1993; Morgan 1998; Symstad 2000; Brandon et al. 2004). Sericea lespedeza has been suggested to invade old-field and cross timbers ecosystems (Eddy and Moore 1998; Brandon et al. 2004), but little data have been presented on the relationships between disturbances, such as fire and grazing, and sericea lespedeza invasion on prairies (Munger 2004). Sericea lespedeza invades rangelands at a rapid rate $(2 \%$ vegetative cover $\cdot$ year $^{-1}$ in our studies), and the invasion rate depends upon the fire and grazing management regime employed in the area. In addition, the invasion can have negative impacts on the cover of the other plant functional groups, and herbicide application to reduce sericea lespedeza dominance did not result in increases in grass or forb biomass in our studies.

\section{Patch Burning and Traditional Management}

The term disturbance has positive and negative connotations depending upon the definition, but is accepted as a natural process in many ecosystems that depend on the regenerative effects of disturbance for their continued existence (Pickett and White 1985; Hobbs and Huenneke 1992). However, distur- 
bance also facilitates the invasion of ecosystems by exotic plant species (Ewel 1986; Rejmanek 1989; Fuhlendorf and Engle 2004). The frequency and timing of the disturbance has a notable impact on the invasion potential, with the interaction of multiple disturbance types having the most profound effects on diversity in grassland plant communities (Collins 1987; Hobbs and Huenneke 1992). In our study, both treatments had the same level of grazing and overall the same amount of fire, but patch burning resulted in focal grazing followed by several years of rest. This fire-grazing interaction suppresses the increase in sericea lespedeza. Grazing animals that select for burned patches might be less likely to be selective at the species level.

In contrast, traditional rangeland management, with homogeneous, less focused disturbance (compared to patch-burning) appeared to provide opportunities for invasion (Fig. 2), and the invasion by sericea lespedeza corresponded to decreases in cover of the native plant community (Table 1). Given the large subsample size, the relationships between sericea lespedeza cover and the cover of other functional groups should have been very strong. However, the weakness of the relationships indicates that sericea lespedeza had very little impact on the plant community in our study, and other factors influenced the plant community dynamics.

Sericea lespedeza invasion rate remained constant in the traditional management treatment throughout the seven years, even following the pasture-wide prescribed burn in 2003. Following this prescribed fire (Fig. 2), both treatments had the same amount of fire across the landscape with the only difference being the timing and pattern of fire. Although the application of fire across the landscape in the traditional management treatment provided new growth for livestock utilization, we propose the large extent of the burned area encouraged grazing selectivity at the species level. In contrast, patch burning led to significantly lower invasion rates (Fig. 2), with summer burning actually reducing sericea lespedeza cover by the third year since fire compared to spring burning. This result is likely a product of focused grazing following a patchburning event (Fuhlendorf and Engle 2004; Vermeire et al. 2004). Because cattle focused their grazing on recently burned patches, nonselective, repeated grazing led to consecutive feeding events on the most recently burned patch and equal avoidance of all species within the unburned patches. Regrowth of many unpalatable species is lower in secondary metabolites, because most plant energy is directed toward growth and reproduction instead of chemical defenses (du Toit et al. 1990; Rosenthal and Kotanen 1994). However, several studies found similar condensed tannin levels in all growth stages of sericea lespedeza plants (Mosjidis et al. 1990). A likely alternative is that focused grazing following the patch-burn maintained sericea lespedeza plants at young maturity levels relative to other patches, thus maintaining utilization. The alteration of grazing preference, intensity, and duration by patch burning changes the level of grazing selectivity from the feeding station to the patch, and could be one limitation to sericea lespedeza invasion in rangeland ecosystems.

\section{Biomass Replacement Following Herbicide Application}

Although most weed control is conducted with the expectation of increased production of desirable species following herbicide application, our data did not consistently support this prediction. Standard broad-spectrum herbicides (i.e., 2,4-D, dicamba, and picloram) do not provide adequate suppression of sericea lespedeza (Altom and Stritzke 1990; Koger et al. 2002). Thirtynine percent of the sites in our studies indicated an increase in desirable biomass production following herbicide application. In over half of the studies, the predictable replacement of sericea lespedeza biomass by grass and forb biomass following herbicide application did not exist, or resulted in only slight change (Figs. 3-4). Although herbicide applications can have a utility in an integrated management program, chemical control of sericea lespedeza does not appear to be a viable means to increase desirable forage production in invaded rangelands. A weak relationship of increased sericea lespedeza and decreased grass production was present only with the most effective, and consequently most expensive, herbicide applications, whereas forbs never showed this trend in our studies. However, the high amount of unexplained variance indicates other factors (biotic and abiotic) have a greater influence on grass and forb biomass than sericea lespedeza biomass.

Although herbicide applications provided an effective control of the existing sericea lespedeza population, we suggest that a management option based on the entire plant community would allow continued suppression of the sericea lespedeza invasion. Swanton and Booth (2004) noted that invasive weed seed bank dynamics demand a population approach for management when the weed is particularly problematic, but only require community management strategies if the plant invasion is not intensely problematic. We propose that in areas where sericea lespedeza populations are in the initial stages of establishment, management strategies such as patch burning provide suppression of the invasion at the level of the recently burned patch, thus managing the entire plant community rather than the individual invader populations. In areas where invasion has exceeded the initial establishment, a combination of sericea lespedeza population control with selective herbicides in an integrated framework with patch burning might provide the best management option.

\section{MANAGEMENT IMPLICATIONS}

Sericea lespedeza is invading rangelands of the southern Great Plains at rates approaching $2 \%$ increases in vegetative cover per year. The impact of invasion on the native plant community function is weakly negative, but more pronounced with traditional management. Focused grazing appears to limit the ability of sericea lespedeza to expand for several years following a prescribed burn, especially following summer fire. This might result from the maintenance of sericea lespedeza plants at young maturity levels due to the regrowth following the patch burn. We propose that historical disturbance regimes, such as patch burning and grazing, could be the key for managing invasive forage species in ecosystems where invasion threatens sustainable function. Modification of grazing selectivity patterns from species level to patch level decisions could limit invasion success without the loss of productivity or function.

Reduction of sericea lespedeza with herbicides is possible, but the associated increase in desirable forages was unpredictable. Although other invasive plant species have been sup- 
pressed with herbicides in combination with other management techniques, our studies did not address the potential application of herbicides in an integrated management plan. A management approach that integrates herbicides and the fire-grazing interaction could be a viable option for long-term control, and future research should investigate this possibility.

\section{ACKNOWLEDGMENTS}

The authors would like to thank Linda Wallace, three anonymous reviewers, and Mindi Howe for their helpful comments in revision of this article. We also thank John Weir, Chris Stansberry, and Ken Nelson for assistance in treatment application and data collection.

\section{LITERATURE CITED}

Altom, J. V., And J. F. StRITZKe. 1992. Sericea lespedeza (Lespedeza cuneata) control with selected post-emergence herbicides. Weed Technology 6:573-576.

Anderson, R. H., S. D. Fuhlendorf, and D. M. Engle. 2006. Soil nitrogen availability in tallgrass prairie under the fire-grazing interaction. Rangeland Ecology Management 59:625-631.

Barnes, R. F., C. J. Nelson, and M. Collins, and K. J. Moore [eds.]. 2003. Forages: an introduction to grassland agriculture. Ames, IA: lowa State Press. $556 \mathrm{p}$.

Brandon, A. L., D. J. Gibson, and B. A. Middelton. 2004. Mechanisms for dominance in early successional old field by the invasive non-native Lespedeza cuneata (Dum. Cours.) G. Don. Biological Invasions 6:483-493.

Clarke, T. D., R. W. Frye, and H. L. Hyland. 1939. Seasonal variation in tannin content of sericea lespedeza. Journal of Agricultural Research 58:131-139.

CluBinE, S. E. 1995. Managing forages to benefit wildlife. In: R. F. Barnes, D. A. Miller, and C. J. Nelson [eds.]. Forages. Vol. II: The science of grassland agriculture. Ames, IA: lowa State University Press. p 263-275.

Coluıns, S. L. 1987. Interaction of disturbances in tallgrass prairie: a field experiment. Ecology. 68:1243-1250.

DonnelLy, E. D. 1954. Some factors that affect palatability in sericea lespedeza Lespedeza cuneata. Agronomy Journal 46:96-97.

DU Tolt J. T., J. P. Bryant, And K. Frisby. 1990. Regrowth and palatability of Acacia shoots following pruning by African savanna browsers. Ecology 71:149-154.

Eddy, T. A., AND C. M. Moore. 1998. Effects of sericea lespedeza (Lespedeza cuneata [Dum.] G. Don) invasion in oak savannas in Kansas. Transactions of the Wisconsin Academy of Sciences, Arts, and Letters 86:57-62.

EwEL, J. 1986. Invasibility: lessons from South Florida. In: H. A. Mooney and J. A. Drake [EDS.]. Ecology of biological invasions of North America and Hawaii. New York, NY: Springer-Verlag. p 214-230.

Funlendorf, S. D., And D. M. Engle. 2001. Restoring heterogeneity on rangelands: ecosystem management based on evolutionary grazing patterns. BioScience $51: 625-632$.

Fuhlendorf, S. D., And D. M. Engle. 2004. Application of the fire-grazing interaction to restore a shifting mosaic on tallgrass prairie. Journal of Applied Ecology 41:604-614.

Fuhlendorf, S. D., W. C. Harrell, D. M. Engle, R. G. Hamilton, C. A. Davis, and D. M. LESLIE, JR. 2006. Should heterogeneity be the basis for conservation? Grassland bird response to fire and grazing. Ecological Applications 16:1706-1716.
Gillen, R. L., F. T. McCollum, M. E. Hodges, J. E. Brummer, and K. W. Tate. 1991. Plant community responses under short duration grazing in tallgrass prairie. Journal of Range Management 44:124-128.

HobBs, R. J., AND L. F. Huenneke. 1992. Disturbance, diversity, and invasion: implications for conservation. Conservation Biology 6:324-336.

Koger, C. H., J. F. Stritzke, And D. C. Cummings. 2002. Control of sericea lespedeza with triclopyr, fluroxypyr, and metsulfuron. Weed Technology 16:893-900.

Mack R. N., D. Simberloff, W. M. Lonsdale, H. Evans, M. Clout, and F. Bazzaz. 2000. Biological invasions: causes, epidemiology, global consequences, and control. Issues in Ecology No.5. Washington, DC: Ecological Society of America. $20 \mathrm{p}$.

Morgan, J. W. 1998. Patterns of invasion of an urban remnant of species-rich grassland in southeastern Australia by non-native plant species. Journal of Vegetation Science. 9:181-190.

Mosudis, C. O., C. M. Peterson, And J. A. Mosudis. 1990. Developmental differences in the location of polyphenols and condensed tannins in leaves and stems of sericea lespedeza, Lespedeza cuneata. Annals of Botany 65(4):355-360.

Munger, G. T. 2004. Lespedeza cuneata. In: Fire effects information system. US Department of Agriculture, Forest Service, Rocky Mountain Research Station, Fire Sciences Laboratory (Producer). Available at: http://www.fs.fed.us/ database/feis/. Accessed 30 November 2005.

National Resources Inventory. 1997. United States Department of AgricultureNatural Resources Conservation Service, Washington, DC. 89 p.

Pickett, S. T. A., and P. S. White [eds.]. 1985. The ecology of natural disturbance and patch dynamics. Orlando, FL: Academic Press. $472 \mathrm{p}$.

Pimental, D., L. Lach, R. Zuniga, and D. Morrison. 2002. Environmental and economic costs associated with non-indigenous species in the United States. In: D. Pimental [ED.]. Biological invasions: economic and environmental costs of alien plant, animal, and microbe species. New York, NY: CRC Press. $p$ 285-303.

Provenza, F. D., E. A. Burritt, T. P. Clausen, J. P. Bryant, P. B. Reichardt, and R. A. Distel. 1990. Conditioned flavor aversion: a mechanism for goats to avoid condensed tannins in blackbrush. American Natutalist 136:810-828.

ReJManek, M. 1989. Invasibility of plant communities. In: J. A. Drake, H. A. Mooney, F. di Castri, R. H. Groves, F. J. Kruger, M. Rejmanek, and M. Williamson [EDs.]. Biological invasions: a global perspective. Chester, England, United Kingdom: Wiley. p 369-388.

Rosenthal, J. P., and P. M. Kotanen. 1994. Terrestrial plant tolerance to herbivory. Trends in Ecology and Evolution 9:145-148.

SAS. 2000. SAS User's guide: Statistics. Cary, NC: SAS Institute. 152 p.

Stitt, R. E., AND I. D. Clarke. 1941. The relationship of tannin content of sericea lespedeza to season. Journal of the American Society of Agronomy 38:1-5.

Swanton, C. J., And B. D. Booth. 2004. Management of weed seedbanks in the context of populations and communities. Weed Technology 18:1496-1502.

Symstad, A. J. 2000. A test of the effects of functional group richness and composition on grassland invasibility. Ecology 8:99-109.

Turner, M. G., R. V. O'Neill, R. H. Gardner, and B. T. Milne. 1989. Effects of changing scale on the analysis of landscape pattern. Landscape Ecology 3:153-162.

Vermeire, L. T., R. B. Mitchell, S. D. Fuhlendorf, and R. L. Gillen. 2004. Patch burning effects on grazing distribution. Journal of Range Management 57:248-252.

Woods, K. D. 1993. Effects of invasion by Lonicera tatarica L. on herbs and tree seedlings in four New England forests. American Midland Naturalist 130:62-74. 